\title{
Amphetamine Sensitization Elevates CaMKIIß mRNA
}

\author{
RACHEL GREENSTEIN, GABRIELA NOVAK,* AND PHILIP SEEMAN \\ Department of Pharmacology, University of Toronto, Toronto, Ontario, Canada M5S 1A8
}

\begin{abstract}
KEY WORDS $\quad$ schizophrenia; gene expression; dopamine supersensitivity; CAMKII $\alpha$; CAMKII $\beta$; CaMK2
\end{abstract}

\begin{abstract}
Recent studies have shown that the elevation in calcium/calmodulindependent protein kinase II (CaMKII) may play an important role in amphetamineinduced dopamine release, as well as in the increase of dopamine D2 receptor highaffinity states in psychosis. Because amphetamine sensitization is a widely used animal model of psychosis or schizophrenia, we investigated whether amphetamine sensitization results in an overall increase in the $\alpha$ and $\beta$ subunits of CaMKII. To answer this question, we measured CaMKII $\alpha$ and $\beta$ subunit mRNA expression using Real-Time Quantitative PCR in amphetamine-sensitized rat striata, compared to saline-treated controls. The results were then standardized to $\beta$-glucuronidase, a housekeeping gene. Our results showed a statistically significant increase in the CaMKII $\beta$ subunit, and an increase in the $\alpha$ subunit which did not reach statistical significance. Because the levels of both CaMKII $\beta$ and CaMKII $\alpha$ play a role in neuronal function and synapse formation, the present finding of an elevated level of CaMKII $\beta$ and $\alpha$ subunit mRNA in the amphetamine-sensitized model of psychosis points to the possibility of dysregulated levels of CaMKII subunits in human psychosis. Synapse 61:827-834, 2007.

○ 2007 Wiley-Liss, Inc.
\end{abstract}

\section{INTRODUCTION}

Although many genes are associated with schizophrenia (Glatt and Jonsson, 2006; Jonsson et al., 2003; Lewis et al., 2003), no single gene has emerged with major effect. Animal models of psychosis, therefore, may be helpful in identifying susceptibility genes (Ko et al., 2006; Seeman et al., 2006a; Seeman et al., $2005 b)$. One such animal model is amphetamine sensitization. This model mimics several biological aspects of schizophrenia (Seeman et al., 2002), including dopamine supersensitivity, a common feature in schizophrenia (Seeman et al., 2007).

Dopamine supersensitivity is associated not only with elevated levels of $\mathrm{D} 2^{\text {High }}$ receptors [i.e., dopamine D2 receptors in their state of high-affinity for dopamine; (Seeman et al., 2005b; Seeman et al., 2006)], but also with an enhanced release of dopamine (Seeman et al., 2005b). In turn, enhanced dopamine release due to sensitization depends on calmodulin $(\mathrm{CaM}), \mathrm{Ca}^{2+}$, and on the activity of CaMKII, and is independent of vesicular dopamine storage (Iwata et al., 1997). Amphetamine-induced dopamine release in sensitized animals is mediated by CaMKIIenhanced outward transport of dopamine rather than by exocytosis, distinguishing it from dopamine release in nontreated rats or after acute administration of amphetamine (Kantor et al., 1999).

Since CaMKII has a central role in amphetamine sensitization, it likely plays an important role in the development of schizophrenia. CaMKII is a neuronal signaling protein that comprises $1-2 \%$ of the protein in the brain (Kolodziej et al., 2000) and is highly enriched in the postsynaptic density fraction (Peng et al., 2004). It is a serine/threonine protein kinase, which modulates synaptic plasticity and plays a role in neuronal development, maturation, and signaling (Fukunaga and Miyamoto, 1999). CaMKII is an evolutionarily conserved protein and is encoded by four genes $(\alpha, \beta, \gamma$, and $\delta$ ) (Tobimatsu and Fujisawa, 1989). Most CaMKII holoenzymes are $12-14$ subunit $\alpha / \beta$

Contract grant sponsors: the Essel Foundation, Constance Lieber, Stephen Lieber, the National Alliance for Research on Schizophrenia and Depression (NARSAD), the Stanley Medical Research Institute (SMRI), the Canadian Institutes for Health Research (CIHR), the Ontario Mental Health Foundation Institutes for Health Research (CIHR), the Ontario Menta
(OMHF), the National Institute on Drug Abuse (NIDA).

*Correspondence to: Gabriela Novak, Department of Pharmacology, University of Toronto, Medical Sciences Building 4344, 1 King's College Circle, Toronto, Canada M5S 1A8. E-mail: gabriela.novak@utoronto.ca

Received 28 December 2006; Accepted 12 April 2007

DOI 10.1002/syn.20429

Published online in Wiley InterScience (www.interscience.wiley.com). 
heteromers (Rosenberg et al., 2006). The ratio of the subunits depends on the type, activity, and the developmental stage of the neuron (Brocke et al., 1999). This ratio also regulates the translocation time of the $\alpha / \beta$ heteromer from $\mathrm{F}$-actin to the postsynaptic density where it phosphorylates its targets (Shen and Meyer, 1999) and also determines the sensitivity of the CaMKII holoenzyme to $\mathrm{Ca}^{2+}$ signals (Brocke et al., 1999). The two subunits differ in their sensitivity to calcium signals. The $\alpha$ subunit is sensitive to signals involving high levels of $\mathrm{Ca}^{2+}$, while the $\beta$ subunit is sensitive to low level calcium signals (Brocke et al., 1999). When $\mathrm{Ca}^{2+}$ enters through NMDA receptors in the dendrites, it causes upregulation of the expression of the $\alpha$ subunit. The $\beta$ subunit, on the other hand, is increased in response to the blockade of AMPA receptors, leading to an increased presence of CaMKII at the postsynaptic density (Thiagarajan et al., 2002). Even in the absence of a sustained elevation in calcium, CaMKII can stay active for a prolonged period of time because of autophosphorylation, forming a molecular memory of calcium signals in the neuron (Miller et al., 1988). CaMKII also regulates the availability and release of synaptic vesicles at the presynaptic terminals by interaction with various proteins; for example, CaMKII phosphorylates synapsin I and promotes dissociation of synapsin I from synaptic vesicles, making more vesicles available for neurotransmitter release (Greengard et al., 1993). In addition, by phosphorylating the N-terminus of dopamine transporter (DAT), CaMKII $\alpha$ plays a key role in mediating the ability of amphetamine to induce efflux of dopamine through the DAT (Fog et al., 2006).

Because the $\beta$ subunit was found to be significantly elevated in postmortem frontal cortex tissues of patients exhibiting schizophrenia and depression (Novak et al., 2006), and because the $\alpha$ and $\beta$ isoforms are important in neurodevelopment, neural function and in mediating amphetamine sensitization, we have measured the levels of the $\alpha$ and $\beta$ subunits in striata from rats sensitized to amphetamine.

\section{MATERIALS AND METHODS Animals}

We used Sprague Dawley male rats, weighing $\sim 200$ $\mathrm{g}$ at the start of the experiments. The rats were randomly divided into two groups, one group $(n=8)$ received an intraperitoneal injection of d-amphetamine sulphate in a volume of $0.5 \mathrm{mg} / 1 \mathrm{ml}$ after dissolving in $0.9 \% \mathrm{NaCl}$, and the second group $(n=6)$ received an intraperitoneal injection of saline. The injections were given on monday, wednesday, and friday for 3 weeks. The amphetamine-treated rats received increasing doses of amphetamine for a total of 9 injections over the 3 weeks period. The dose increased from 1 to $3 \mathrm{mg} / \mathrm{kg}$ with an increase of $1 \mathrm{mg} /$ $\mathrm{kg}$ each week. Following the last injection, the animals were left drug-free for 26 days before they were euthanized by carbon dioxide overdose. The entire striatum tissue was dissected without subdivision into sections in order to provide sufficient tissue for extraction of total RNA. The weighted average for each tissue was between $20-25 \mathrm{mg}$.

The withdrawal period induced an intense behavioural sensitization in these animals (Seeman et al., 2002). The brain striata were removed and frozen at $-70^{\circ} \mathrm{C}$ until used.

\section{Extraction of total RNA from tissues}

Seven hundred fifty microliter of TRIzol reagent (Invitrogen; Life Technologies, Carlsbad, CA) was added to the tissue, according to the manufacturer's guidelines, to extract total RNA from tissues. (Polytron PT-10 probe, Brinkmann instruments, Westbury, NY). The tissue was homogenized as a whole with no separation between the postsynaptic and the presynaptic regions because of the small size of the striatum and the requirement for a large amount of RNA for determination of RNA quantity. The homogenized samples were incubated at room temperature for $5 \mathrm{~min}, 200 \mu \mathrm{l}$ chloroform were added, and the tubes were shaken vigorously for $15 \mathrm{~s}$. The tubes were incubated at room temperature for $3 \mathrm{~min}$ and centrifuged at $10,000 \mathrm{rpm}$ at $4^{\circ} \mathrm{C}$ for $15 \mathrm{~min}$. The aqueous upper phase containing RNA was transferred to a new tube. The RNA was washed with 1 volume of $70 \% \mathrm{EtOH} /$ Depc'd water, and transferred immediately onto a Qiagen RNeasy Mini Spin Column. The samples were centrifuged for $15 \mathrm{~s}$ at 10,000 rpm. To remove contaminants, the columns were washed with $350 \mu l$ of buffer RW1 and centrifuged for $15 \mathrm{~s}$ at 11,000 rpm. Residual DNA was removed by adding DNase1 incubation mix (10 $\mu$ l of DNase1 and $70 \mu$ l buffer RDD) directly onto the RNeasy silica-gel membrane and incubating it at room temperature for $15 \mathrm{~min}$. The columns were washed again with $350 \mu$ l RW1 buffer and centrifuged for $15 \mathrm{~s}$ at $11,000 \mathrm{rpm}$. To remove any additional contamination, we washed the columns twice with $500 \mu$ l of RPE buffer and centrifuged, first for $15 \mathrm{~s}$ at $11,000 \mathrm{rpm}$, and the second time for $2 \mathrm{~min}$ at $11,000 \mathrm{rpm}$ to dry the silica-gel membrane.

To elute the RNA, we pipetted $40 \mu$ l of RNase-free water directly onto the RNeasy silica-gel membrane, let it stand for $1 \mathrm{~min}$, and then centrifuged it for $1 \mathrm{~min}$ at $11,000 \mathrm{rpm}$. We repeated the elution with another $20 \mu \mathrm{l}$ of RNase-free water and centrifuged the membrane for another min. The final total RNA concentration was between 750-1000 ng per $\mu \mathrm{l}$ of water, as determined by optical density. This solution was further diluted with DEPC water to $3 \mu \mathrm{g}$ RNA per $8 \mu \mathrm{l}$ water for cDNA synthesis. 


\section{First strand cDNA synthesis}

The SUPERSCRIPT III ${ }^{\mathrm{TM}}$ First-Strand Synthesis System for RT-PCR (Invitrogen, Carlsbad, CA) was used to prepare cDNA, using oligo $(\mathrm{dT})_{20}$ and $3 \mu \mathrm{g}$ of total RNA. The reaction was terminated by incubation at $70^{\circ} \mathrm{C}$ for $15 \mathrm{~min}$ and the sample was then chilled on ice for $5 \mathrm{~min}$. The RNA was removed by adding $1 \mu \mathrm{l}$ of RNase $\mathrm{H}$ and incubating at $37^{\circ} \mathrm{C}$ for $20 \mathrm{~min}$. The resulting sample containing $21 \mu \mathrm{l} \mathrm{cDNA}$ was stored at $-20^{\circ} \mathrm{C}$ for later use.

\section{Real-time quantitative polymerase chain reaction}

The real-time PCR Mx4000 ${ }^{\mathrm{TM}}$ Multiplex Quantitative PCR System (Stratagene, La Jolla, CA) was used to quantitate and analyze cDNA. Specific primers were designed for each target gene by using the Primer Express software (Perkin-Elmer Applied Biosystems, Foster City, CA) and synthesized by SIGMAGenosys (Oakville, Ontario). A standard template was prepared for each target gene by conventional PCR using Taq DNA Polymerase (QIAGEN, Mississauga, $\mathrm{ON})$. We used the same primer pairs which were later used in the real-time quantitative PCR. We confirmed that the PCR product obtained is the correct target gene by verifying the correct size of the fragment on an agarose gel after amplification of the template. The PCR products were extracted from a gel using the MinElute ${ }^{\mathrm{TM}}$ Gel Extraction Kit (Qiagen, Mississauga, $\mathrm{ON}$ ) and the concentration was measured by optical density. We used Brilliant ${ }^{\mathrm{TM}}$ SYBR $^{\circledR}$ Green QPCR Core Reagent Kit (Stratagene, La Jolla, CA) to prepare the reaction mixture for the real-time quantitative PCR, the company protocol was followed. The total reaction volume of $25 \mu$ l contained $0.25 \mu l(10$ $\mathrm{mM})$ of forward and $0.25 \mu \mathrm{l}(10 \mathrm{mM})$ of reverse primer. For each set of primers a dissociation curve analysis was preformed to verify that only a single product is amplified. The $\beta$-glucuronidase forward primer $\left(5^{\prime}\right.$ to $\left.3^{\prime}\right)$ was AGAGGTTACGGTTCAGTGC and the reverse primer ( $5^{\prime}$ to $\left.3^{\prime}\right)$ was TCCCCCTTG TGTTGGTTCA. The CAMKII $\alpha$ forward primer $\left(5^{\prime}\right.$ to $3^{\prime}$ ) was AGGATGAAGACACCAAAGTGC and the reverse primer $\left(5^{\prime}\right.$ to $\left.3^{\prime}\right)$ was GGTTCAAAGGCTGTC ATTCC. The CAMKII $\beta$ forward primer $\left(5^{\prime}\right.$ to $\left.3^{\prime}\right)$ was ACCTCATTTGAGCCTGAAGC and the reverse primer $\left(5^{\prime}\right.$ to $\left.3^{\prime}\right)$ was CAGGATAGTGGTGTGGATCG. SYBR Green dye was diluted 1:2000 and the Rox reference dye was diluted 1:500. $3 \mu \mathrm{l}$ of 1/10 diluted cDNA sample (equivalent to $43 \mathrm{ng}$ of total RNA) was used per reaction. The cycling parameters were $95^{\circ} \mathrm{C}$ for 10 min to activate the SureStart ${ }^{\mathrm{TM}}$ Taq polymerase, followed by 40 cycles of denaturation at $95^{\circ} \mathrm{C}$ for $30 \mathrm{~s}$, reannealing at $55^{\circ} \mathrm{C}$ (for CAMKII $\alpha$ ), $54^{\circ} \mathrm{C}$ (for $\mathrm{CAMKII} \beta$ ) and $60^{\circ} \mathrm{C}$ (for $\tilde{\beta}$ glucuronidase) for $45 \mathrm{~s}$, and extension at $72^{\circ} \mathrm{C}$ for $45 \mathrm{~s}$. To account for the varying RNA quality between individual samples and the differences in efficiency in cDNA synthesis of different cDNA batches, the mRNA expression of each target gene was normalized against the mRNA expression of a house keeping gene, $\beta$-glucuronidase. In order to minimize the effect of background noise and well to well variation on the results observed, our data were normalized against the Rox reference dye and the algorithm of adaptive baseline. Each reaction was repeated at least four times, using two independent cDNA dilutions and each of the fourteen RNA samples is represented by three independent cDNA syntheses.

\section{RESULTS}

Before proceeding with cDNA measurements, we confirmed that the rat tissues were indeed supersensitive to dopamine by measuring their proportion of $\mathrm{D} 2{ }^{\text {High }}$ receptors in two representative striata from the amphetamine treated group, a reliable index of dopamine supersensitivity (Seeman et al., 2005b; Seeman et al., 2007). We measured the levels of $\mathrm{D} 2{ }^{\mathrm{High}}$ receptors using a range of concentrations of $\left[{ }^{3} \mathrm{H}\right](+)$ PHNO D2 agonist, which has a high affinity for the dopamine $\mathrm{D} 2{ }^{\text {High }}$ receptors, in the presence and absence of guanine nucleotide. Guanine nucleotide converts all the $\mathrm{D} 2{ }^{\text {High }}$ receptors into their state of low affinity for dopamine; however, because $\left[{ }^{3} \mathrm{H}\right](+) \mathrm{PHNO}$ binds also to the low-affinity state of dopamine D2 receptors, we measured the total amount of $\left[{ }^{3} \mathrm{H}\right](+)$ PHNO bound to D2 receptors and the amount of bound $\left[{ }^{3} \mathrm{H}\right](+) \mathrm{PHNO}$ which was sensitive to the presence of guanine nucleotide. The last measurement reflected the component of the $\mathrm{D} 2{ }^{\mathrm{High}}$ receptors. (Seeman et al., 2007). Indeed, the striata from the amphetamine-sensitized rats revealed that the proportion of dopamine $\mathrm{D} 2{ }^{\mathrm{High}}$ receptors was 2.2-fold higher than the control tissues (data not shown), confirming previously published data (Seeman et al., 2005b; Seeman et al., 2007).

We measured the cDNA concentration of CaMKII $\alpha$ and CaMKII $\beta$ using real-time quantitative PCR. We normalized it against the expression of $\beta$-glucuronidase, a house keeping gene, to reduce the effects of mRNA manipulation, such as variations in cDNA synthesis and mRNA degradation. (Novak et al., 2006). To determine the significance of changes in mRNA levels, we used the Student $t$-distribution test (TDIST), a two tailed-test.

\section{Expression of CaMKII $\alpha$ mRNA}

The average concentration of CaMKII $\alpha$ mRNA in the striata of control rats was $3.0 \pm 0.2 \mathrm{pg} \mathrm{mRNA} / \mu \mathrm{g}$ total RNA (mean $\pm \mathrm{SE} ; n=6$ ). The average CaMKII $\alpha$ mRNA concentration in the amphetamine sensitized group was $3.3 \pm 0.1 \mathrm{pg} \mathrm{mRNA} / \mu \mathrm{g}$ total RNA (mean \pm SE; $n=8$ ), a $10 \%$ increase (TDIST; $P=0.03$ ) (Fig. 1). 
CaMKII $\alpha$ per total RNA

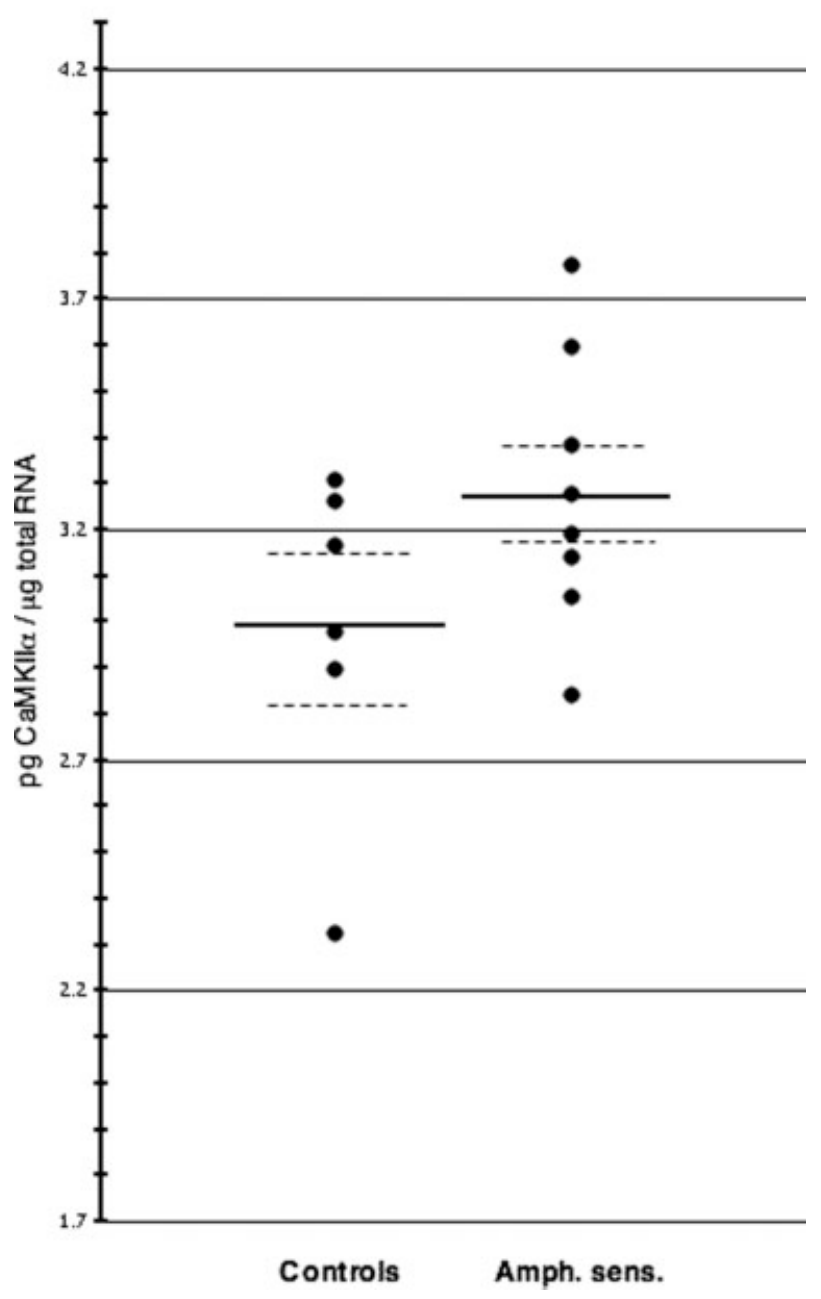

Fig. 1. CaMKII $\alpha$ in amphetamine sensitized rat striatum. The amount of CaMKII $\alpha$ transcript in the control striata and in the amphetamine sensitized tissues. The average was $3.0 \pm 0.2 \mathrm{pg} \mathrm{mRNA} /$ $\mu \mathrm{g}$ total RNA (mean $\pm \mathrm{SE} ; n=6$ ), and $3.3 \pm 0.1 \mathrm{pg} \mathrm{mRNA} / \mu \mathrm{g}$ total RNA (mean $\pm \mathrm{SE} ; n=8$ ), respectively. This was a $10 \%$ increase (TDIST; $P=0.03$ ).

\section{Expression of CaMKII $\beta$ mRNA}

The average concentration of CaMKII $\beta$ mRNA in the striata of the control rats was $3.5 \pm 0.1 \mathrm{pg}$ $\mathrm{mRNA} / \mu \mathrm{g}$ total RNA (mean $\pm \mathrm{SE} ; n=6$ ). The average CaMKII $\beta$ mRNA concentration in the amphetamine-sensitized group was $4.0 \pm 0.2 \mathrm{pg} \mathrm{mRNA} / \mu \mathrm{g}$ total RNA (mean $\pm \mathrm{SE} ; n=8$ ), a $15 \%$ increase (TDIST; $P=0.01$ ) (Fig. 2).

\section{Expression of $\boldsymbol{\beta}$-glucuronidase}

The average concentration of $\beta$-glucuronidase mRNA in the striata of the control rats was $30 \pm 1 \mathrm{fg}$ mRNA/ $\mu \mathrm{g}$ total RNA (mean $\pm \mathrm{SE} ; n=6$ ). The average concentration of $\beta$-glucuronidase mRNA in the striata of the amphetamine sensitized group was $32 \pm 1 \mathrm{fg} \mathrm{mRNA} / \mu \mathrm{g}$
CaMKIIß per total RNA

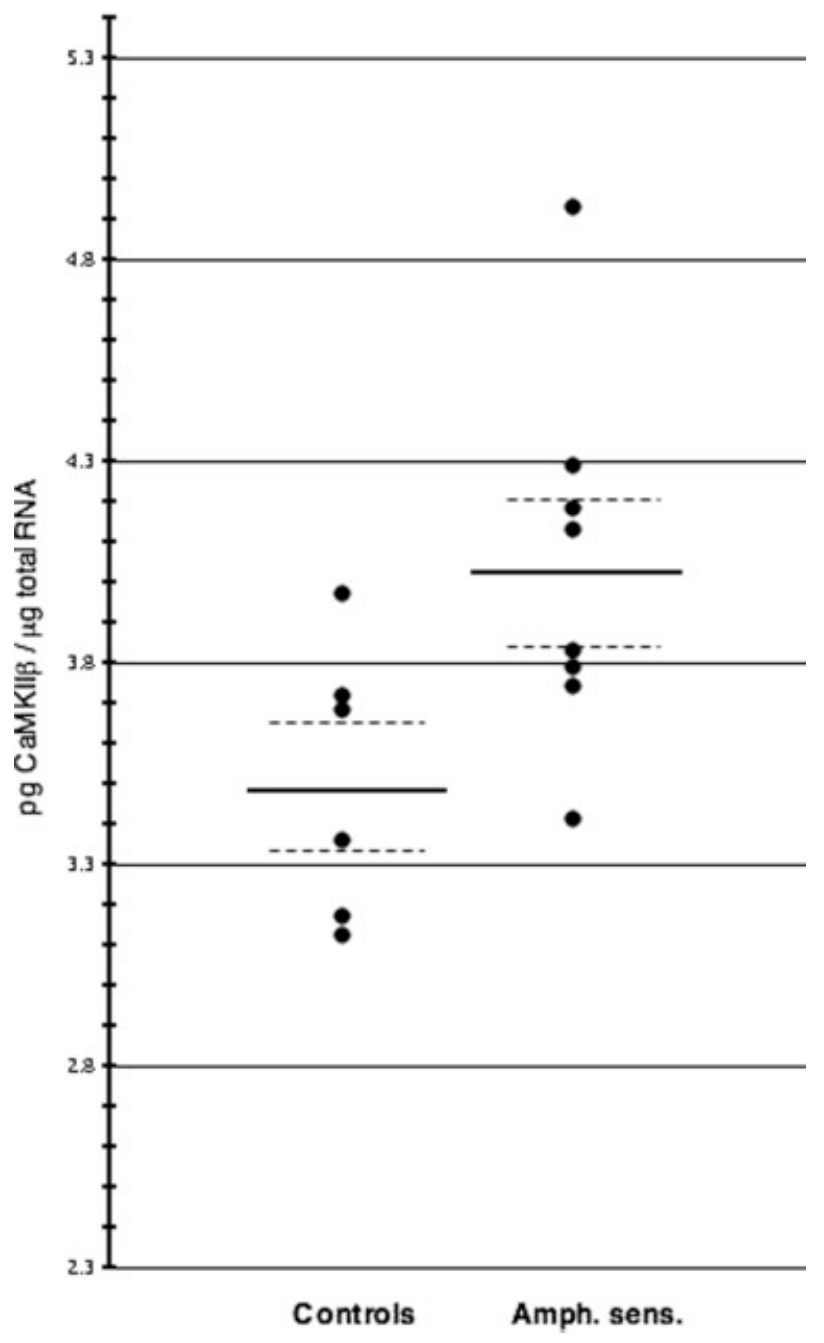

Fig. 2. CaMKII $\beta$ in amphetamine sensitized rat striatum. The amount of CaMKII $\beta$ mRNA transcript in the control striata and in the amphetamine sensitized tissues. The average concentration of CaMKII $\beta$ mRNA in the striata of the control rats was $3.5 \pm 0.1 \mathrm{pg}$ $\mathrm{mRNA} / \mu \mathrm{g}$ total RNA (mean $\pm \mathrm{SE} ; n=6$ ) and in the amphetamine sensitized group it was $4.0 \pm 0.2 \mathrm{pg} \mathrm{mRNA} / \mu \mathrm{g}$ total RNA (mean \pm $\mathrm{SE} ; n=8$ ), a $15 \%$ increase (TDIST; $P=0.01$ ).

total RNA (mean $\pm \mathrm{SE} ; n=8$ ). There was no statistically significant difference between the two groups.

\section{Normalization of CaMKII $\alpha$ and CaMKII $\beta$ to $\beta$-glucuronidase}

CaMKII mRNA levels of each cDNA sample were standardized to the housekeeping gene $\beta$-glucuronidase by dividing the CaMKII $\alpha$ or CaMKII $\beta$ concentration by the concentration of $\beta$-glucuronidase. The average concentration of CaMKII $\alpha$ in the control rats after the normalization was $98 \pm 5 \mathrm{pg}$ CaMKII $\alpha / \mathrm{pg}$ $\beta$-glucuronidase (mean $\pm \mathrm{SE} ; n=6$ ). The average concentration of CaMKII $\alpha$ in the amphetamine-sensitized rats after the normalization was $103 \pm 4 \mathrm{pg}$ $\mathrm{CaMKII} \alpha / \mathrm{pg} \beta$-glucuronidase (mean $\pm \mathrm{SE} ; n=8$ ). 


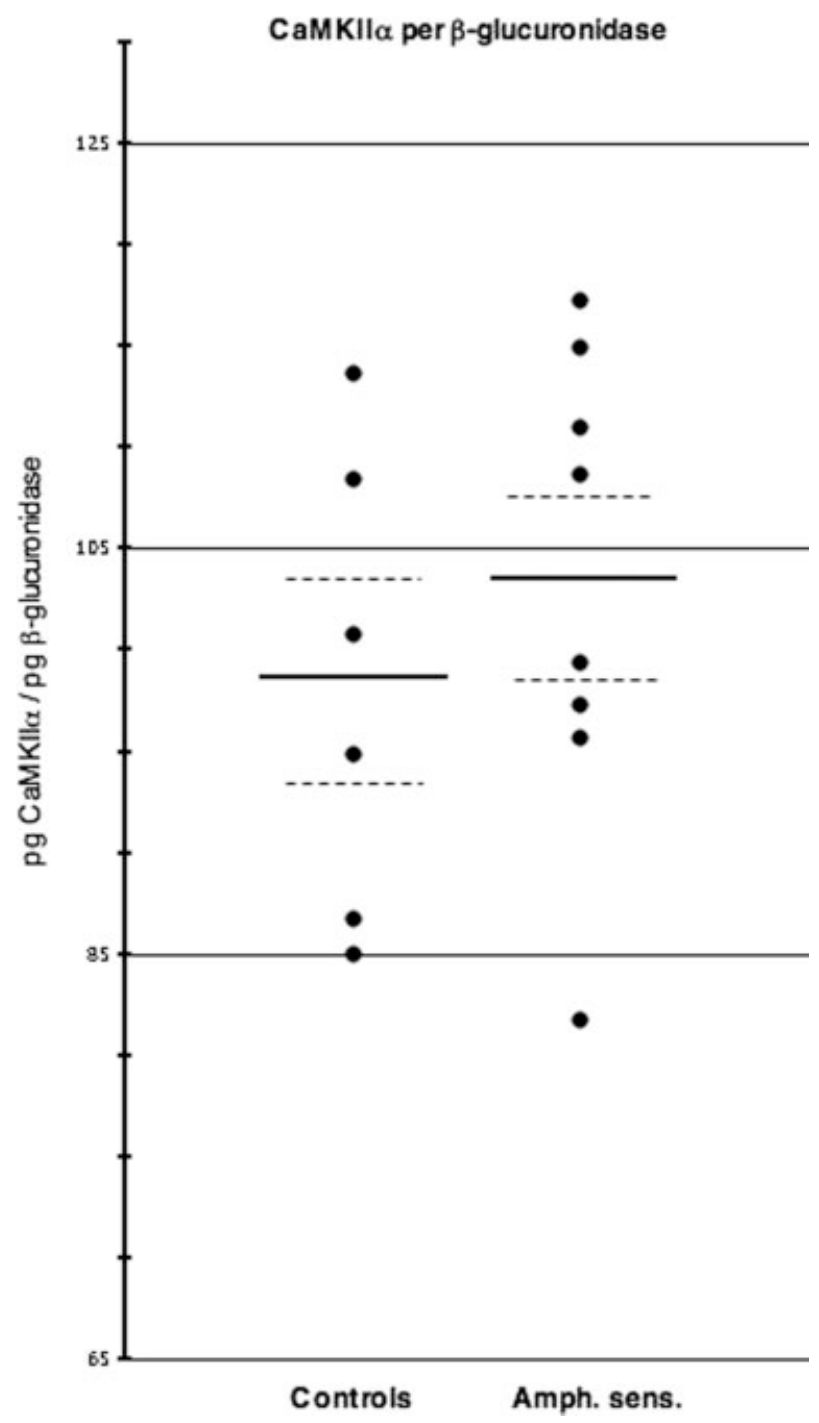

Fig. 3. CaMKII $\alpha / \beta$-glucuronidase in amphetamine sensitized rat striata. The amount of CaMKII $\alpha$ transcript in the control rat striata and in the sensitized tissues after standardization to $\beta$-glucuronidase. The average is $98 \pm 5 \mathrm{pg} \mathrm{CaMKII} \alpha / \mathrm{pg} \beta$-glucuronidase (mean $\pm \mathrm{SE} ; n=6$ ) and $103 \pm 4 \mathrm{pg}$ CaMKII $\alpha / \mathrm{pg} \beta$-glucuronidase (mean \pm $\mathrm{SE} ; n=8$ ), respectively. The $6 \%$ increase in CaMKII $\alpha$ was not statistically significant (TSIDT; $P=0.2$ ).

The 6\% increase in CaMKII $\alpha$ was not statistically significant (TSIDT; $P=0.2$ ) (Fig. 3).

The average concentration of CaMKII $\beta$ in the control rats after the normalization was $116 \pm 3 \mathrm{pg}$ $\mathrm{CaMKII} \beta / \mathrm{pg} \beta$-glucuronidase (mean $\pm \mathrm{SE} ; n=6$ ). The average concentration of CaMKII $\beta$ in the amphetamine-sensitized rats after the normalization was $125 \pm 4 \mathrm{pg}$ CaMKII $\beta / \mathrm{pg} \beta$-glucuronidase (mean \pm $\mathrm{SE} ; n=8)$. The $8 \%$ increase in CaMKII $\beta$ was statistically significant (TDIST; $P=0.02$ ) (Fig. 4).

\section{DISCUSSION}

The present results confirm that dopamine supersensitivity and the increase in the high-affinity states
CaMKII $\beta$ per $\beta$-glucuronidase

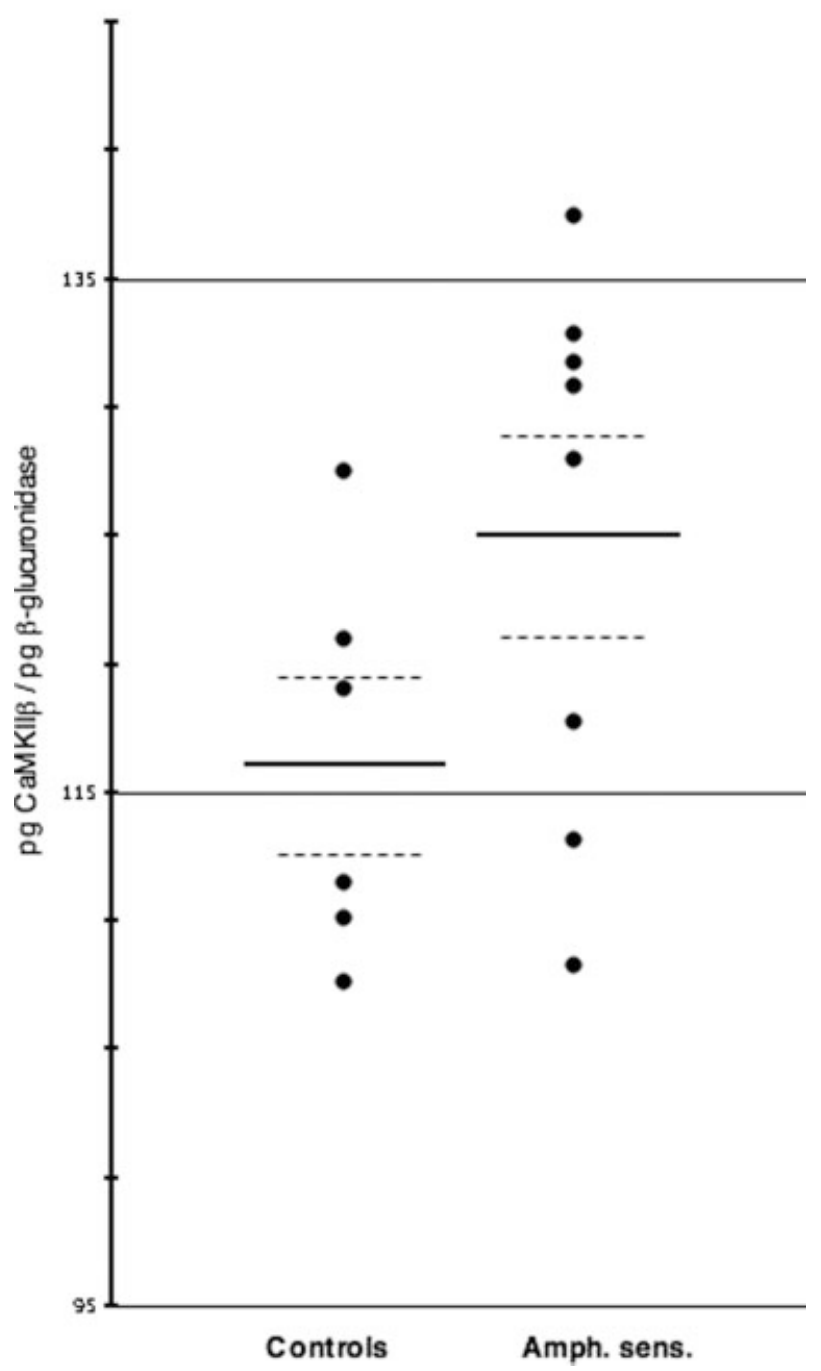

Fig. 4. CaMKII $\beta / \beta$-glucuronidase in amphetamine sensitized rat striata. The amount of CaMKII $\beta$ transcript in the control rat striata and in the sensitized tissues after standardization to $\beta$-glucuronidase. The average is $116 \pm 3 \mathrm{pg}$ CaMKII $\beta / \mathrm{pg} \beta$-glucuronidase (mean $\pm \mathrm{SE} ; n=6$ ) and $125 \pm 4 \mathrm{pg} \mathrm{CaMKII} \beta / \mathrm{pg} \beta$-glucuronidase (mean $\pm \mathrm{SE} ; n=8$ ), respectively. This $8 \%$ increase in CaMKII $\beta$ is statistically significant (TDIST; $P=0.02$ ).

of dopamine D2 receptors are associated with an elevation in both CaMKII $\beta$ and CaMKII $\alpha$; however, only CaMKII $\beta$ elevation reaches statistical significance. These findings support the involvement of CaMKII, especially CaMKII $\beta$, in schizophrenia, as well as in amphetamine sensitization (Novak et al., 2006).

CaMKII plays an important role in mediating responses to changes in synaptic activity that lead to neuronal development, maturation, and signaling (Fukunaga and Miyamoto, 1999); therefore, any change in the concentration of CaMKII $\alpha$ and $\beta$ subunits would have a major effect on the neuronal activity. The precise maintenance of the $\alpha$ and $\beta$ subunit ratio is essential because it is directly related to neural 
maturation, determining under which conditions the synapse will undergo either LTP or LTD (Fukunaga and Miyamoto, 1999). Consequently, CaMKII $\alpha$ knockout mice show defects in expression of LTP, LTD, and in spatial learning (Silva et al., 1992).

The concentration of $\mathrm{CaMKII} \alpha$ and $\beta$ subunits is critical in neurodevelopment, especially during the period of synaptic network formation, because the concentrations of both CaMKII subunits in the brain changes in a specific pattern during the postnatal period. In the early stages of development the concentration of CaMKII $\alpha$ is low, but it increases steadily and seems to be limited to cells that are no longer dividing (Bayer et al., 1999; Brocke et al., 1995). Compared to the $\alpha$ subunit, $\beta$ expression begins early in development, rises until day 3 after birth, when expression reaches the adult level, and continues to be expressed strongly in the adult rat brain (Bayer et al., 1999; Fink et al., 2003; Karls et al., 1992). The $\alpha: \beta$ ratio changes throughout development. In the forebrain of a 10-day old rat, the ratio between $\alpha$ and $\beta$ is $1: 1$, compared with an adult, where the ratio is 2.3:1 (Kelly et al., 1987; McGuinness et al., 1985; Miller and Kennedy, 1985). Increased CaMKII levels, especially of CaMKII $\beta$, which are observed in schizophrenia patients and in amphetamine sensitized rats, may play a role in abnormal neurodevelopment and subsequent predisposition to schizophrenia (Novak et al., 2006). In addition, absence of maturation, induced by CaMKII upregulation, leads to neuropathology and behavioral defects in adulthood (Keshavan et al., 1994).

The $\alpha$ and $\beta$ subunits hold very different functions; $\beta$ controls dendritic morphology and the number of synapses and synaptic formation, whereas $\alpha$ controls synaptic strength (Fink et al., 2003). This plays an important role not only during development, but also in the mature brain. The ratio between $\alpha$ and $\beta$ subunits is inversely regulated in response to activity, the $\alpha$ subunit levels rising during higher firing levels and $\beta$ subunit levels increasing during lower activity. The result is reinforcement of existing synapses during high firing activity and formation of new ones during lower activity (Fink et al., 2003; Thiagarajan et al., 2002).

The role of the $\beta$ subunit in the $\alpha / \beta$ hetero-oligomer is to dock the holoenzyme to polymerized F-actin and upon stimulation to translocate the whole functional unit to the postsynaptic density (PSD), its main site of action. A small number of the $\beta$ subunits is able to localizes a much larger number of the $\alpha$ subunits to synaptic and cytoskeletal sites, most importantly the PSD (Shen et al., 1998). In contrast, $\alpha$ homo-oligomers remain localized to soma and dendrites (Blichenberg et al., 2001; Mayford et al., 1996; Merrill et al., 2005). Hence, even a small change in CaMKII $\beta$ levels has the potential to result in a large effect on CaMKII concentration at the PSD, which is its main site of action, and, consequently, on the activity of the neuron.

Schizophrenia is a disorder with structural and functional abnormalities distributed in the thalamocortico-limbic regions of the brain. Hypofunction of a subpopulation of cortico-limbic NMDA receptors may participate in this pathophysiology (Tsai and Coyle, 2002). Noncompetitive antagonists of the NMDA receptor, such as phencyclidine, ketamine, and MK 801 can cause psychotic-like cognitive impairment (Javitt and Zukin, 1991; Krystal et al., 1994; Krystal et al., 2000). The PSD contains diverse types of ionotropic glutamate receptors such as NMDA, AMPA, and metabotropic receptors, all of which are substrates for CaMKII (Yoshimura et al., 2002). CaMKII not only greatly influences their function (Leonard et al., 1999; Swope et al., 1999), but also influences their developmental expression (Ben-Ari et al., 1997). In addition, NMDA receptor activity influences the expression of the $\alpha$ subunit, and AMPA receptors influence the expression of the $\beta$ subunit of CaMKII (Thiagarajan et al., 2002). In striatal neurons both dopamine and glutamate receptors are densely expressed and CaMKII is the most potent kinase that regulates NR2B phosphorylation (Liu et al., 2006). Chronic intermittent stimulation of striatal dopaminergic receptors enhances the sensitivity of NMDA receptors in the striata (Kotter, 1994). The D2 receptor mediates phosphorylation of NR2B subunit by activation of CaMKII and subsequently affects glutamatergic transmission (Oh et al., 1999). Liu, et al., showed that acute cocaine administration reduced NMDA receptor phosphorylation by CaMKII through a D2 receptor-dependent mechanism (Liu et al., 2006). They observed that in response to cocaine administration, D2 receptors directly interact with the NR2B subunit and disturb the NR2B-CaMKII binding, subsequently preventing NR2B phosphorylation by CaMKII. In addition, the interruption of the interaction between the dopamine-glutamate signaling led to disrupting of various forms of synaptic and behavioral plasticity in response to stimulants (Liu et al., 2006). Accordingly, we assume that amphetamine sensitization and concomitant DAT phosphorylation and D2 receptor stimulation may escalate the disruption between NMDA receptor and CaMKII, affecting CaMKII $\alpha$ levels and upregulating CaMKII $\beta$, resulting in increase in AMPA receptors at the PSD and a decrease in NMDA receptors, leading to NMDA hypofunction. When we consider the NMDA hypofunction theory, one should keep in mind that the noncompetitive antagonists of the NMDA receptor have a combined action on both dopamine and NMDA receptors and might act as dopamine partial agonists. Furthermore, glutamate receptor agonists induce a very mild improvement in symptoms when used in the treatment of psychosis (Seeman et al., 2005a). 
Other evidence of a significant role for CaMKII in neuron function is its ability to phosphorylate tyrosine hydroxylase and tryptophan hydroxylase (Yamauchi, 2005), because the production of monoamines is important in psychiatric illnesses.

To conclude, CaMKII is important for the normal function of D2, NMDA, and AMPA receptors. Any alteration in the concentration of its $\alpha$ and $\beta$ subunits would result in impairment in neuronal development, maturation, and signaling. The data show that dopamine supersensitivity is associated with a statistically significant elevation in the $\beta$ subunit mRNA levels, but not the $\alpha$ subunit mRNA levels of CaMKII. Since the elevation of the CaMKII subunit mRNA level was relatively low, we would suggest for future research to examine different brain regions, such as the hippocampus and the frontal cortex.

\section{ACKNOWLEDGMENTS}

The authors thank the Medland family, the O'Rorke family, the Rockert family, and the estate of the late Dr. Karolina Jus for their support. Supported by the Canadian Institutes for Health Research, the Ontario Mental Health Foundation, the Essel Foundation, and by Constance E. Lieber and Stephen Lieber.

\section{REFERENCES}

Bayer KU, Lohler J, Schulman H, Harbers K. 1999. Developmental expression of the CaM kinase II isoforms: Ubiquitous $\gamma$ - and $\delta$-CaM kinase II are the early isoforms and most abundant in the developing nervous system. Brain Res Mol Brain Res 70:147-154.

Ben-Ari Y, Khazipov R, Leinekugel X, Caillard O, Gaiarsa JL. 1997. GABAA, NMDA and AMPA receptors: A developmentally regulated 'menage a trois'. Trends Neurosci 20:523-529.

Blichenberg A, Rehbein M, Muller R, Garner CC, Richter D, Kindler S. 2001. Identification of a cis-acting dendritic targeting element in the mRNA encoding the $\alpha$ subunit of $\mathrm{Ca}^{2+} /$ calmodulin-dependent protein kinase II. Eur J Neurosci 13:1881-1888.

Brocke L, Srinivasan M, Schulman H. 1995. Developmental and regional expression of multifunctional $\mathrm{Ca}^{2+} /$ calmodulin-dependent protein kinase isoforms in rat brain. J Neurosci 15:6797-6808.

Brocke L, Chiang LW, Wagner PD, Schulman H. 1999. Functional implications of the subunit composition of neuronal CaM kinase II. J Biol Chem 274:22713-22722

Fink CC, Bayer KU, Myers JW, Ferrell JE, Jr, Schulman H, Meyer T. 2003. Selective regulation of neurite extension and synapse formation by the $\beta$ but not the $\alpha$ isoform of CaMKII. Neuron 39:283297.

Fog JU, Khoshbouei H, Holy M, Owens WA, Vaegter CB, Sen N, Nikandrova Y, Bowton E, McMahon DG, Colbran RJ, Daws LC, Sitte HH, Javitch JA, Galli A, Gether U. 2006. Calmodulin kinase II interacts with the dopamine transporter $\mathrm{C}$ terminus to regulate amphetamine-induced reverse transport. Neuron 51:417-429.

Fukunaga K, Miyamoto E. 1999. Current studies on a working model of CaM kinase II in hippocampal long-term potentiation and memory. Jpn J Pharmacol 79:7-15.

Glatt SJ, Jonsson EG. 2006. The Cys allele of the DRD2 Ser311Cys polymorphism has a dominant effect on risk for schizophrenia: evidence from fixed- and random-effects meta-analyses. Am J Med Genet B: Neuropsychiatr Genet 141:149-154.

Greengard P, Valtorta F, Czernik AJ, Benfenati F. 1993. Synaptic vesicle phosphoproteins and regulation of synaptic function. Science 259:780-785.

Iwata SI, Hewlett GH, Ferrell ST, Kantor L, Gnegy ME. 1997. Enhanced dopamine release and phosphorylation of synapsin I and neuromodulin in striatal synaptosomes after repeated amphetamine. J Pharmacol Exp Ther 283:1445-1452.
Javitt DC, Zukin SR. 1991. Recent advances in the phencyclidine model of schizophrenia. Am J Psychiatry 148:1301-1308.

Jonsson EG, Sillen A, Vares M, Ekholm B, Terenius L, Sedvall GC. 2003. Dopamine D2 receptor gene Ser311Cys variant and schizophrenia: Association study and meta-analysis. Am J Med Genet B: Neuropsychiatr Genet 119:28-34.

Kantor L, Hewlett GH, Gnegy ME. 1999. Enhanced amphetamineand $\mathrm{K}^{+}$-mediated dopamine release in rat striatum after repeated amphetamine: Differential requirements for $\mathrm{Ca}^{2+}$ - and calmodulindependent phosphorylation and synaptic vesicles. J Neurosci 19: 3801-3808.

Karls U, Muller U, Gilbert DJ, Copeland NG, Jenkins NA, Harbers K. 1992. Structure, expression, and chromosome location of the gene for the $\beta$ subunit of brain-specific $\mathrm{Ca}^{2+}$ /calmodulin-dependent protein kinase II identified by transgene integration in an embryonic lethal mouse mutant. Mol Cell Biol 12:3644-3652.

Kelly PT, Shields S, Conway K, Yip R, Burgin K. 1987. Developmental changes in calmodulin-kinase II activity at brain synaptic junctions: Alterations in holoenzyme composition. J Neurochem 49:1927-1940. Keshavan MS, Anderson S, Pettegrew JW. 1994. Is schizophrenia due to excessive synaptic pruning in the prefrontal cortex? The Feinberg hypothesis revisited. J Psychiatr Res 28:239-265.

Ko F, Tallerico T, Seeman P. 2006. Antipsychotic pathway genes with expression altered in opposite direction by antipsychotics and amphetamine. Synapse 60:141-151.

Kolodziej SJ, Hudmon A, Waxham MN, Stoops JK. 2000. Threedimensional reconstructions of calcium/calmodulin-dependent $(\mathrm{CaM})$ kinase $\mathrm{II} \alpha$ and truncated $\mathrm{CaM}$ kinase II $\alpha$ reveal a unique organization for its structural core and functional domains. J Biol Chem 275:14354-14359.

Kotter R. 1994. Postsynaptic integration of glutamatergic and dopaminergic signals in the striatum. Prog Neurobiol 44:163-196.

Krystal JH, Karper LP, Seibyl JP, Freeman GK, Delaney R, Bremner JD, Heninger GR, Bowers MB, Jr, Charney DS. 1994. Subanesthetic effects of the noncompetitive NMDA antagonist, ketamine, in humans. Psychotomimetic, perceptual, cognitive, and neuroendocrine responses. Arch Gen Psychiatry 51:199-214.

Krystal JH, Bennett A, Abi-Saab D, Belger A, Karper LP, D'Souza DC, Lipschitz D, Abi-Dargham A, Charney DS. 2000. Dissociation of ketamine effects on rule acquisition and rule implementation: Possible relevance to NMDA receptor contributions to executive cognitive functions. Biol Psychiatry 47:137-143.

Leonard AS, Lim IA, Hemsworth DE, Horne MC, Hell JW. 1999 Calcium/calmodulin-dependent protein kinase II is associated with the N-methyl-D-aspartate receptor. Proc Natl Acad Sci USA 96:3239-3244.

Lewis CM, Levinson DF, Wise LH, DeLisi LE, Straub RE, Hovatta I, Williams NM, Schwab SG, Pulver AE, Faraone SV, Brzustowicz LM, Kaufmann CA, Garver DL, Gurling HM, Lindholm E, Coon H, Moises HW, Byerley W, Shaw SH, Mesen A, Sherrington R, O’Neill FA, Walsh D, Kendler KS, Ekelund J, Paunio T, Lonnqvist J, Peltonen L, O'Donovan MC, Owen MJ, Wildenauer DB, Maier W, Nestadt G, Blouin JL, Antonarakis SE, Mowry BJ, Silverman JM, Crowe RR, Cloninger CR, Tsuang MT, Malaspina D, HarkavyFriedman JM, Svrakic DM, Bassett AS, Holcomb J, Kalsi G, McQuillin A, Brynjolfson J, Sigmundsson T, Petursson H, Jazin E, Zoega T, Helgason T. 2003. Genome scan meta-analysis of schizophrenia and bipolar disorder, part II: Schizophrenia. Am J Hum Genet 73:34-48.

Liu XY, Chu XP, Mao LM, Wang M, Lan HX, Li MH, Zhang GC, Parelkar NK, Fibuch EE, Haines M, Neve KA, Liu F, Xiong ZG, Wang JQ. 2006. Modulation of D2R-NR2B interactions in response to cocaine. Neuron 52:897-909.

Mayford M, Baranes D, Podsypanina K, Kandel ER. 1996. The 3'untranslated region of CaMKII $\alpha$ is a cis-acting signal for the localization and translation of mRNA in dendrites. Proc Natl Acad Sci USA 93:13250-13255

McGuinness TL, Lai Y, Greengard P. 1985. $\mathrm{Ca}^{2+} /$ calmodulindependent protein kinase II. Isozymic forms from rat forebrain and cerebellum. J Biol Chem 260:1696-1704.

Merrill MA, Chen Y, Strack S, Hell JW. 2005. Activity-driven postsynaptic translocation of CaMKII. Trends Pharmacol Sci 26:645-653.

Miller SG, Kennedy MB. 1985. Distinct forebrain and cerebellar isozymes of type II $\mathrm{Ca}^{2+}$ /calmodulin-dependent protein kinase associate differently with the postsynaptic density fraction. J Biol Chem 260:9039-9046.

Miller SG, Patton BL, Kennedy MB. 1988. Sequences of autophosphorylation sites in neuronal type II CaM kinase that control Ca2(+)-independent activity. Neuron 1:593-604.

Novak G, Seeman P, Tallerico T. 2006. Increased expression of calcium/calmodulin-dependent protein kinase II $\beta$ in frontal cortex in schizophrenia and depression. Synapse 59:61-68. 
Oh JD, Vaughan CL, Chase TN. 1999. Effect of dopamine denervation and dopamine agonist administration on serine phosphorylation of striatal NMDA receptor subunits. Brain Res 821:433-442.

Peng J, Kim MJ, Cheng D, Duong DM, Gygi SP, Sheng M. 2004. Semiquantitative proteomic analysis of rat forebrain postsynaptic density fractions by mass spectrometry. J Biol Chem 279:21003-21011.

Rosenberg OS, Deindl S, Comolli LR, Hoelz A, Downing KH, Nairn AC, Kuriyan J. 2006. Oligomerization states of the association domain and the holoenyzme of $\mathrm{Ca}^{2+} / \mathrm{CaM}$ kinase II. FEBS J 273:682694.

Seeman P, Tallerico T, Ko F, Tenn C, Kapur S. 2002. Amphetaminesensitized animals show a marked increase in dopamine D2 high receptors occupied by endogenous dopamine, even in the absence of acute challenges. Synapse 46:235-239.

Seeman P, Ko F, Tallerico T. 2005a. Dopamine receptor contribution to the action of PCP, LSD and ketamine psychotomimetics. Mol Psychiatry 10:877-883.

Seeman P, Weinshenker D, Quirion R, Srivastava LK, Bhardwaj SK, Grandy DK, Premont RT, Sotnikova TD, Boksa P, El-Ghundi M, O’Dowd BF, George SR, Perreault ML, Mannisto PT, Robinson S, Palmiter RD, Tallerico T. 2005b. Dopamine supersensitivity correlates with D2 ${ }^{\text {High }}$ states, implying many paths to psychosis. Proc Natl Acad Sci USA 102:3513-3518.

Seeman P, Schwarz J, Chen JF, Szechtman H, Perreault M, McKnight GS, Roder JC, Quirion R, Boksa P, Srivastava LK, Yanai K, Weinshenker D, Sumiyoshi T. 2006. Psychosis pathways converge via D2 ${ }^{\text {high }}$ dopamine receptors. Synapse 60:319-346.

Seeman P, McCormick PN, Kapur S. 2007. Increased dopamine D2(High) receptors in amphetamine-sensitized rats, measured by the agonist $[(3) \mathrm{H}](+) \mathrm{PHNO}$. Synapse 61:263-267.
Shen K, Meyer T. 1999. Dynamic control of CaMKII translocation and localization in hippocampal neurons by NMDA receptor stimulation. Science 284:162-166.

Shen K, Teruel MN, Subramanian K, Meyer T. 1998. CaMKII $\beta$ functions as an F-actin targeting module that localizes $\mathrm{CaMKII} \alpha / \beta$ heterooligomers to dendritic spines. Neuron 21:593606.

Silva AJ, Paylor R, Wehner JM, Tonegawa S. 1992. Impaired spatial learning in $\alpha$-calcium-calmodulin kinase II mutant mice. Science 257:206-211.

Swope SL, Moss SI, Raymond LA, Huganir RL. 1999. Regulation of ligand-gated ion channels by protein phosphorylation. Adv Second Messenger Phosphoprotein Res 33:49-78.

Thiagarajan TC, Piedras-Renteria ES, Tsien RW. 2002. $\alpha$ - and $\beta C a M K I I$. Inverse regulation by neuronal activity and opposing effects on synaptic strength. Neuron 36:1103-1114.

Tobimatsu T, Fujisawa H. 1989. Tissue-specific expression of four types of rat calmodulin-dependent protein kinase II mRNAs. J Biol Chem 264:17907-17912.

Tsai G, Coyle JT. 2002. Glutamatergic mechanisms in schizophrenia. Annu Rev Pharmacol Toxicol 42:165-179.

Yamauchi T. 2005. Neuronal $\mathrm{Ca}^{2+} /$ calmodulin-dependent protein kinase II-Discovery, progress in a quarter of a century, and perspective: Implication for learning and memory. Biol Pharm Bull 28:1342-1354.

Yoshimura Y, Shinkawa T, Taoka M, Kobayashi K, Isobe T, Yamauchi T. 2002. Identification of protein substrates of $\mathrm{Ca}(2+) /$ calmodulin-dependent protein kinase II in the postsynaptic density by protein sequencing and mass spectrometry. Biochem Biophys Res Commun 290:948-954. 